\title{
The Creative Economy as a Factor of Economic Development: Three Different Cases, One Common Objective
}

\author{
Santos LOPEZ-LEYVA ${ }^{1}$, Gilberto GUZMÁN-SOLANO ${ }^{2}$ \\ 1 Universidad Autónoma de Baja California, Campus Tijuana. Calzada Universidad no. 14418, \\ Parque Industrial Internacional, C.P. 22427, Tijuana, Baja California, MX; (D) slleyva@uabc.edu.mx \\ (corresponding author) \\ 2 Universidad Autónoma de Baja California, Campus Tijuana. Calzada Universidad no. 14418, \\ Parque Industrial Internacional, C.P. 22427, Tijuana, Baja California, MX; \\ ing_webber@hotmail.com
}

\begin{abstract}
This article presents an economic analysis of the behavior of the creative economy of three countries: the United Kingdom (UK), the Republic of Korea (South Korea), and Mexico. The experience and the actions implemented by the first two countries are useful to suggest the implementation of public policies for Mexico. As is well known, the creative economic sector contributes to economic development and generates wealth for the nations. The activities included in this type of economy may vary from country to country since theorists, organizations, and governments use different approaches and there are current discussions regarding what activities to include in this sector. The question is why developed economies are most worried about this kind of topic and the developing countries not so much, despite that in the future both kinds of economies will face problems from technological unemployment. Since the beginning of this century, the UK and South Korea have implemented practices regarding creative economies. For example, these regions have created specialized organizations to foster creative economic sectors with the perspective of technological development and by offering them financial support. In 2013, South Korea created a program to support creative and cultural industries, particularly oriented to the international market; the program was coordinated by the Ministry of Science, ICT, and Future Planning (MSIP). On the other hand, the government of Mexico has not implemented integral policies to assist or encourage creative sectors, where most of the support towards these sectors has come from private organizations and individual initiatives. The purpose of this article is to use the experiences of the UK and South Korea to suggest ideas and learning mechanisms that can be adopted by Mexico to implement practices, programs, and public policies to improve its creative sector.
\end{abstract}

\section{Keywords}

creative economy; economic development; creative industries; cultural industries; cultural products; orange economy.

\section{Introduction}

Along the XXI century, a new economic paradigm known as "creative economy" emerged and became highly relevant. In the past, some of the current creative activities were exclusively considered as part of the entertainment and leisure businesses. Recently, these activities have drawn attention among scholars and governments worldwide, because these activities, most of which are not susceptible to automation, employ a great number of human resources, creating wealth and a positive impact on the quality of life within the regions where they are developed. Therefore, it is relevant to research and compare policies and practices that have been implemented to foster creative industries by different regions and countries, so that the developing economies can have more information available to design and implement plans and strategies to strengthen their own "creative economies."

\section{How to cite}

Lopez-Leyva, S., \& Guzmán-Solano, G. (2021). The Creative Economy as a Factor of Economic Development: Three Different Cases, One Common Objective. Culture. Society. Economy. Politics, 
This study includes the analysis of three economies: the United Kingdom (UK), the Republic of Korea (South Korea), and Mexico. The differences among them enrich the knowledge, experiences, and information that can be found about the "creative economy." This type of economy is inclusive and the activities may vary by country according to their culture, customs, history, and idiosyncrasies.

It is well known that economies have evolved from agricultural to digital and ultimately creative economies. Such evolution has been as follows: a) agricultural-based economy; b) industrial-based economy; c) industrial export-based economy; d) services-based economy; e) knowledge-based economy; f) digital-based economy; g) creative economy. Being the most developed countries, the first ones to implement policies and programs regarding creative economies.

The evolution of the economic systems is one of the reasons we chose these three countries; the UK and South Korea have evolved from being agricultural economies to creative economies, despite their differences in idiosyncrasy, culture, geography, and commercial partners. On the other hand, Mexico, even though it is in a good position among the Latin American countries, has not evolved into a creative economy, but has a great potential to implement policies and programs towards being a creative economy. In 2013, during the presidency of Mrs. Park Geun-hye, South Korea implemented a national plan that encouraged creative economies, particularly and specially oriented to the products and services exchange in foreign markets. Mexico has the potential to develop this type of economy, although the country does not have a national plan to encourage it, nor a system to measure the performance of the activities that can be considered as creatives. The government's actions have been incipient. "Creative industries" have been developed and encouraged by some clusters, universities, and the private sector; this last one has been in charge of measuring the performance of their own businesses.

This paper describes the positive effects of "creative economy" for the economic development of the three countries mentioned above, by analyzing their GDP percentage participation, level of employment (number of created jobs), commerce (sales of creative goods and services), the balance of trade, their main commercial partners, among other indicators related to economic development. It should be noted that with the collected information it was not possible to perform a comparative analysis, but it was possible to show the dynamic and the growth of the creative economy in the three countries, and also highlight the support that the different governments have given to this sector.

\section{Research theoretical framework}

Creative industries not only include goods and services produced within the cultural industry, although this is part of the creative economy; cultural industry activities depend more on innovation, such as the different types of research and development of software. The term "creative industries" started to be used in the design of national cultural policies at the end of the last century; for example, Australia designed a National Cultural Policy during the nineties, and the Department for Digital, Culture, Media, and Sports in the UK made a transition from cultural industries to creative industries. Furthermore, this concept originated when creativity, urban development, and city planning started to be linked. Charles Landry's works (2001) about creative cities had a great impact in disseminating this idea. Lord Smith of Finsbury, the British Minister of Culture, was the first, had managed to implement creative industry into his government policies and to highlight the economic importance of creativity (Veselá \& Klimová, 2014)

Richard Florida (2013) is an important international reference. He studied groups of creative people that cities need to achieve greater economic development. The population he describes goes beyond the workers dedicated to activities within the 
creative and cultural industries; it also includes technician workers, managers, and professionals, since together, they produce innovation in different sectors (UNDP \& UNESCO, 2013).

The critics of creative industries allude that the term "creativity" is used in a very general way, without any specific delimitation, leaving out the expressions that are part of creative services and products. While the advocates of "creative economy" highlight the importance of cultural and creative economies for fostering economic growth through the creation of value, besides being a substantial element for innovation systems; from its part, cultural industries stimulate new ideas, technologies, and processes of transformative changes (UNDP \& UNESCO, 2013).

The concept of "creative economy" was mentioned for the first time in 2001 in the work of John Howkins (2013): "The creative Economy. How people make money from ideas," where he classifies the industries that belong to the creative economy in the UK; they range from arts to science and technology, which according to their characteristics and production processes are mainly related to creativity. But since this concept is very wide it also includes R\&D departments and the toy industry.

According to the United Nations Conference of Trade and Development (UNCTAD), a creative economy includes the following products and services: art artifacts, audiovisuals, design, multimedia, performing arts, publishing, visual arts, advertising, architecture, R\&D, recreational and cultural services. South Korea's government also includes haute cuisine, video games development, and cinematography.

Buitrago and Duque (2013) in a publication sponsored by the Inter-American Development Bank (IDB) developed a concept similar to "creative economy" which they called "the orange economy." They offered a wider approach to creative activities and presented relevant data about the economic impact that creative activities have in the world and the multicultural enrichment they represent.

Hartley, Wen, and Li (2015) offered a wider definition, based on three assumptions or principles:

- Creative industries are not reduced to an elite of skilled and talented artists or specialized firms, but they include all the workers that participate in them;

- they are not exclusive of a sector but they are part of all the economic sectors; and

- they are not exclusive to rich and developed countries; they can be developed in all economies.

It is important to differentiate the creative economy from other concepts that have been disseminated by other scholars in the socio-cultural and economic fields. There is a great variety of concepts such as cultural industries, creative industries, leisure industries, entertainment industries, content industries, property rights industries, cultural economy, and orange economy, among others, that are partially or completely related to the creative economy activities.

Daubaraité and Startiené (2015, p. 130) turn to UNCTAD (2008) and establish that the most important characteristics of the creative industries are:

1. Their production requires some input of human creativity;

2. They are vehicles for symbolic messages to those who consume them;

3. They contain, at least potentially, some intellectual property that is attributable to individuals or groups producing the good or service.

It is appropriate to distinguish the difference between creative and cultural industries, the main difference is that creative industries (CI) are oriented to make a profit using creativity and cultural heritage, while cultural industries seek to reduce social exclusion, form a national identity and preserve cultural heritage (Daubaraité and Startiené, 2015). 
Bilan, Vasilyeva, Krylii, and Shilibetova (2019) determine that CI is a synthetic phenomenon through which culture, economy, and social policy can be linked. Cultural industries are part of CI, which are focused on business development, while the cultural industries are mostly linked to cultural expressions and other non-economic activities. (Daubaraité, 2018)

Among the most relevant international researches regarding "creative economies" are the ones developed by the IBD; one of its most recent publications was "Orange Economy. Innovations you may not know were from Latin American and the Caribbean" written by Luzardo, De Jesus \& Lopez (2017). They highlight data about employment and creative products and services that have originated in the region of Latin America and the Caribbean.

The UNDP and UNESCO published the "Creative Economy Report 2013. Special Edition. Widening Local Development Pathways" where they present an exhaustive analysis of different regions from the planet, demonstrating that the implementation of proper public policies in creative sectors can achieve economic growth and improve quality life. This analysis includes different projects that have been successfully implemented in each continent.

Economic evolution has contributed to advances in technology, but at the same time some activities that used to be done by human beings have been replaced by automated processes, creating unemployment in certain industries, some of them are energy, agriculture, communication, and some activities such data processing, production processes, machinery, teaching, monitoring, surveillance, commercial transactions, commerce, wars, etc.

An important assumption for this research is that higher standardization and automatization reduce the number of employees that a company needs to carry out its functions and its goal of accumulating wealth. Even though there might be some exceptions, the entrepreneurial logic is that standardization and automatization would represent higher profits, therefore, in the future human resources would be expendable and only the most innovative, creative, and knowledgeable workers would be kept employed.

Frey and Osborne (2017) carried out an analysis through an algorithm with artificial intelligence to find out what were jobs that were more susceptible to being automated in the United States. The algorithm estimated that $47 \%$ of the jobs were susceptible to automation with the advancement and use of technologies. Frey (2019) assumes that at some point, the algorithms will have the ability to effectively reproduce human intelligence. The creative economy is a good way to reduce unemployment and increase the added value of a country's economy (Daubaraité \& Startiené, 2015) because, in a study about the creative industries carried out these authors, they found that the three areas of the national economy that show the greatest influence of these industries are: the fight against unemployment, participation in GDP and foreign trade.

According to Guilera (2020), for a creative product or service to be easily accepted is necessary they comply with some of the following characteristics: 1) satisfy basic needs, 2) provide pleasure, 3) emotionally seducers, 4) rationally accepted, which means to be efficient and fast, helping to reduce everyday troubles, price-efficient and, 5) have a vision of future.

\section{Methodology}

As we said before, the article reviews the behavior of three countries in the creative economy, although the data refer to different dimensions, it is intended to demonstrate the importance that the creative economy has taken in the three nations. For the United 
Kingdom, the work focuses on reviewing statistics related to production, number of enterprises, employment, and sales in the creative sector. While with information of United Nations Conference of Trade and Development (UNCTAD) for the period of 2009 to 2014, the dynamics of foreign trade in the creative economy was analyzed for South Korea. Finally, in the case of Mexico, it was possible to review the dimension of the creative sector, for which a public policy has not been defined. The three economies are very different, according to the classification of economic models of countries presented by Gregory and Stuart (2014); the United Kingdom is located in the Saxon model, where the state and society have formed institutions in charge of promoting creative economies. The Asian model is the one that prevails in South Korea, where the State promotes exports and fosters the infant industries with the potential to export. Mexico is among the developing countries, which have weak policies to support the economy and show a lack of institutions that can assume this responsibility.

The Information provided by the National Endowment for Science, Technology, and Arts (NESTA) was used to analyze the creative economy in the United Kingdom. First, we described part of the work that has been done by NESTA in matters of local and national policies regarding the creative sector. The analysis consists of reviewing the number of businesses, sales volume, employment, sales volume per employee, and the number of employees by business unit among the creative industries, which are: advertising, architecture, design, film, radio and TV, music, and performing, arts, publishing, software and digital. The data consist of two periods, the first one goes from 2007 to 2010, and the second one goes from 2011 to 2014.

Regarding the creative economy of the Republic of Korea, we retrieved data about exports and imports of creative goods from 2009 to 2014, for the following categories: art crafts, audiovisuals, design, new media, performing arts, publishing, and visual arts. We also present and analyze information about their main commercial partners, including the amount (in millions of euros and percentages) of exports and imports of creative products.

To analyze the performance of the creative sectors in Mexico, we used the information presented by Valdivia, Quintana, Mendoza, and Rodriguez (2020). Data are from 2005 to 2018 and include information about creative occupations, employment in creative industries, creative specialists, non-creative employees working in creative industries, and creative employees working in non-creative sectors. We also make a comparative analysis for the years of 2014, 2015, and 2019 regarding the creative industries in Mexico, which are: publications, filming, video, and sound, broadcasting activities, computer programming, consultancy services, architecture, R\&D, advertising, and market research, design and photography, libraries and museums, gambling, sports, and entertainment. We also analyze the structure and the growth rate of creative jobs, besides other indicators such as aggregate value, number of jobs, and the trade balance for the years 2015 and 2018.

The purpose is that, based on the public policies implemented by South Korea and the United Kingdom, actions are recommended to improve the behavior of creative industries in Mexico and increase their participation in the GDP of this country.

\section{Analysis and discussion by country \\ Creative Industries in the United Kingdom and their impact on economic development}

The United Kingdom is one of the most advanced regions in research studies regarding creative economies. They have developed a system that allows them to measure the impact of creative activities in their society, commerce, the creation of jobs, social inclusion, among other indicators. The local governments together with the Creative 
Industries Council (CIC) have developed a five years plan that would foster economic activities based on creativity. They support their studies with statistical information provided by NESTA.

According to NESTA, creative economy and arts can greatly contribute to the sociocultural and economic well-being of society. However, these activities are undervalued and their needs and potential have not been acknowledged by the policymakers and the advocates of innovation.

Since 2009, NESTA Foundation's goal has been to promote and strengthen the value of "creative economies." Between 2017 and 2020, they worked in three important strategies to achieve the goal: 1) promote the creative industries as the core of the local and national government policies, 2) help the cultural and artistic organizations to prosper and reach their potential, and 3) develop a World Class Research Center.

During the last decade, the Foundation has promoted the high value of a "creative economy" by suggesting the design of public policies, supporting cultural and artistic organizations with the implementation of digital technologies and new financing sources. Their research has demonstrated that creative industries are crucial to having competitive advantages. To develop their studies, they have found support from the Creative Industries Policy and Evidence Centre (PEC). This center was created by the Arts and Humanities Research Council; it is integrated by ten universities from the UK and it has the best scholars and specialists in the subject.

From 2012 to 2015, the Digital R\&D Fund for the Arts invested seven million sterling pounds on 53 artistic organizations, so they could be able to use digital technology in new business models. In 2016, NESTA launched the Digital Arts and Culture Accelerator to explore if a model of technological advancement could have been transferred to the cultural and arts sectors.

Table 1. Evolution of the creative industries in the United Kingdom, 2007 and 2014

\begin{tabular}{|l|c|c|}
\hline Industry & $\mathbf{2 0 0 7}$ & $\mathbf{2 0 1 4}$ \\
\hline All creative industries-business & 187,848 & 258,801 \\
\hline All creative industries-turnover (Euros) & $85,534,178,760.00$ & $113,802,925,240.00$ \\
\hline All creative industries-employment & 954,289 & $1,185,332$ \\
\hline All creative industries-turn-pw (Euros) & $89,630.80$ & $96,009.20$ \\
\hline All creative industries-work-pb & 5.08 & 4.58 \\
\hline
\end{tabular}

Conversion from GBP to Euros: 1 GBP = .68 Euro (2007) constant prices.

Source: Own elaboration with data from NESTA, 2014, retrieved on June 15, 2021

Table 1 shows that from 2007 to 2014 businesses in creative industries increased by 70,953 units, which represented a growth of $37.77 \%$. The sales volume of the industries increased by $28,268,746,480$ euros that is a growth of $33.04 \%$. Employment also registered an increase of 231,043 employees, representing a growth of $24.21 \%$ in seven years.

In terms of worker efficiency, in 2007, each employee within the creative industries generated 89,630.80 euros, while in 2014 one employee was able to generate $96,009.20$ euros. An interesting fact is that even when the number of workers employed by a business unit decreased for the period, they still generated more income; this could be explained by the introduction of technologies that eased some of the activities carried out within these industries.

Table 2. The number of companies by creative industry in the United Kingdom Periods: 2007-2011 and 2011-2014

\begin{tabular}{|l|c|c|c|}
\hline Creative Industries & $\mathbf{2 0 0 7 - 2 0 1 1}$ & $\mathbf{2 0 1 1 - 2 0 1 4}$ & \% Growth rate \\
\hline Advertising & 18,070 & 22,195 & 22.83 \\
Architecture & 11,057 & 13,765 & 24.49
\end{tabular}


Source: Own elaboration with data from NESTA, 2014, retrieved on June 15, 2021.

From table 2, when comparing the information of the two given periods, it is observed that the industries with a higher growth percentage in creating new enterprises were: 1) design, 2) software and digital, 3) architecture, 4) advertising, 5) film, radio, and TV, 6) publishing and, 7) music and performing arts, in that order. Although considering the absolute number of business created, the ranking changed as follow: 1) software and digital industry with 24,354 new companies; 2) design, with 4,715 new companies; 3) advertising, 4,125; 4) film, radio, and TV, 3,854; 5) architecture, 2,708; 6) music and performing arts, 971; and 7) publishing, with 569, respectively.

Table 3. Sales volume by creative industry in the United Kingdom Periods: 2007-2010 and 2011-2014 (Information in euros)

\begin{tabular}{|l|c|c|c|}
\hline Creative Industries & $\mathbf{2 0 0 7 - 2 0 1 1}$ & $\mathbf{2 0 1 1 - 2 0 1 4}$ & \% Growth rate \\
\hline Advertising & $15,551,216,514.00$ & $18,339,997,800$ & 17.93 \\
Architecture & $3,638,650,624.00$ & $3,895,699,600$ & 7.06 \\
Design & $2,848,757,578.40$ & $3,629,360,600$ & 27.40 \\
Film, Radio and T.V. & $18,276,142,230.00$ & $20,783,384,000$ & 13.72 \\
Music and Performing Arts & $21,673,640.00$ & $22,333,920$ & 3.05 \\
Publishing & $13,533,225,258.00$ & $11,844,920,000$ & -12.48 \\
Software and Digital & $31,312,760,054.00$ & $38,696,736,200$ & 23.58 \\
\hline
\end{tabular}

Conversion from GBP to Euros: 1 GBP = .68 Euro (2007) constant prices.

Source: Own elaboration with data from NESTA, 2014), retrieved on June 15, 2021

When analyzing the sales volume by industry, their performance varies depending on the indicator: sales growth by percentage or with absolute numbers. Therefore, if we consider the growth rate, the industries can be ranked as follows: 1) design, 2) software, 3) advertising, 4) film, radio, and T.V., 5) architecture, 6) music and performing arts, and 7) publishing; this last one showed a decrease. However, when analyzing the changes in the amount of sales in absolute numbers, their performance from best to worst is as follows: 1) software and digital industry, with an increase of 7,383,976,146 euros, 2) advertising, 2,788,781,286 euros, 3) film, radio, and T.V. 2,507,241,770 euros, 4) design, $780,603,022$ euros, 5) architecture, 257,048,976 euros, 6) music and performing arts, 660,280 euros, and 7) publishing, $-16,88,305,258$ euros. This last industry is the only one that drastically reduced its sales.

Table 4. Number of Employees by creative industry in the United Kingdom Periods: 2007-2010 and 2011-2014

\begin{tabular}{|l|c|c|l|}
\hline Creative Industries & $\mathbf{2 0 0 7 - 2 0 1 0}$ & $\mathbf{2 0 1 1 - 2 0 1 4}$ & \% Growth rate \\
\hline Advertising & 108,153 & 135,895 & 25.65 \\
Architecture & 59,985 & 63,243 & 5.43 \\
Design & 39,042 & 51,625 & 32.23 \\
Film, radio, and T.V. & 154,001 & 162,993 & 5.84 \\
Music and performing arts & 101,065 & 107,501 & 6.37 \\
Publishing & 158,748 & 143,449 & -9.64 \\
Software and digital & 364,757 & 440,775 & 20.84 \\
\hline
\end{tabular}

Source: Own elaboration with data from NESTA, 2014, retrieved on June 15, 2021.

According to table 4, the most dynamic industries on creating jobs were design, advertising and software and digital, while the less dynamic were film, radio, and T.V., architecture and publishing, this last one lost jobs in the second period.

The number of jobs created from the first to the second period was as follows: 1) software and digital, 76,018 more jobs; 2) advertising, 27,742; 3) design, 12,583; 4) film, radio, and T.V., 8,992; 5) music and performing arts, 6,436; 6) architecture, 3,258; and, 7) 
The Creative Economy as a Factor of Economic Development: Three Different Cases, One Common Objective

publishing, $-15,299$ workers.

Table 5. Sales per worker in the creative industries of the United Kingdom Periods: 2007-2010 and 2011-2014 (Amounts in euros)

\begin{tabular}{|l|c|c|c|}
\hline Creative Industries & $\mathbf{2 0 0 7 - 2 0 1 0}$ & $\mathbf{2 0 1 1 - 2 0 1 4}$ & \% Growth rate \\
\hline Advertising & $143,792.80$ & $134,959.60$ & -6.14 \\
Architecture & $60,662.80$ & $61,601.20$ & 1.55 \\
Design & $72,970.80$ & $70,305.20$ & -3.65 \\
Film, Radio and T.V. & $118,673.60$ & $127,513.60$ & 7.45 \\
Music and Performing Arts & $66,123.20$ & $68,727.60$ & 3.94 \\
Publishing & $85,251.60$ & $82,572.40$ & -3.14 \\
Software and Digital & $85,843.20$ & $87,794.80$ & 2.27 \\
\hline
\end{tabular}

Conversion from GBP to Euros: $1 \mathrm{GBP}=.68$ Euro (2007) constant prices.

Source: Own elaboration with data from NESTA, 2014, retrieved on June 15, 2021.

The industries that had the highest turnover growth per worker were a film, radio and TV, music and performing arts, and Software and digital, in that order. On the other hand, the industries with the worst performance were design, publishing, and advertising; these last three with negative numbers.

By analyzing the absolute growth in the volume of sales per employee, the most efficient workers were from the film, radio, and T.V. industry, generating 8,840 euros more than the previous period; in second place there was music and performing arts with an increase of 2,604.40 euros per worker, in third place was software and digital, with an increase of 1,951.60 euros, and in fourth place was the architecture industry with 938.40 euros. The three industries with lower sales productivity were Design, Publishing, and Advertising, with negative numbers, -2,665.60 euros, -2,679.20 euros, and -8,833.20 euros, respectively.

Table 6. The average number of employees per company in the creative industries in the United Kingdom

Periods: 2007-2010 and 2011-2014

\begin{tabular}{|l|c|c|c|}
\hline \multicolumn{1}{|c|}{ Creative Industries } & $\mathbf{2 0 0 7 - 2 0 1 0}$ & $\mathbf{2 0 1 1 - 2 0 1 4}$ & \% Growth rate \\
\hline Advertising & 5.99 & 6.12 & 2.30 \\
Architecture & 5.43 & 4.59 & -15.31 \\
Design & 2.56 & 2.59 & 1.00 \\
Film, radio, and T.V. & 6.38 & 5.82 & -8.73 \\
Music and performing arts & 3.17 & 3.27 & 3.22 \\
Publishing & 16.83 & 14.34 & -14.78 \\
Software and digital & 4.27 & 4.02 & -5.97 \\
\hline
\end{tabular}

Source: Own elaboration with data from NESTA, 2014, retrieved on June 15, 2021.

The industries that show the higher increase in the number of employees per enterprise were music and performing arts, advertising, and design, in that order. The other four industries that needed/hired fewer workers per firm were software $(-5.97 \%)$; film, radio, and TV (-8.73\%); publishing (-14.78\%); and architecture $(-15.31 \%)$.

Overall, the United Kingdom has promoted public policies and implemented plans toward strengthening and fostering the development of creative industries, which is seen in the creation of institutions like NESTA, CIC, and PEC. The economic activity and the dynamism of these industries have grown, reflected in a higher number of new enterprises, particularly in software and design. These two sectors showed a better performance in the creation of new enterprises and volume of sales.

\section{South Korea and the commerce of creative products}

In 2013, the president of South Korea, Ms. Park Geun-hye announced her vision to create a "Second Miracle on the Han River" through a new policy focused on developing a "creative economy" (Cornell, 2014, p. 3). The country developed a strategy through an institutional economic plan to transit toward this new type of economy, including 
important economic agents and organizations, such as their Stock Exchange Agency, corporate enterprises, small and medium businesses institutions, government ministries, among others.

In this section, we present tables with data that show the commercial performance of the creative industries located in South Korea. This information was retrieved from the United Nations Conference of Trade and Development (UNCTAD) from 2009 to 2014.

Table 7. Foreign Commerce of Creative Goods by Category, South Korea, 2009-2014 (Millions of euros)

\begin{tabular}{|c|c|c|c|c|c|c|c|c|c|c|c|c|}
\hline \multirow{2}{*}{ Year } & \multicolumn{2}{|r|}{$\begin{array}{l}\text { ᄋ̊ } \\
\text { 오 }\end{array}$} & \multicolumn{2}{|r|}{ 옹 } & \multicolumn{2}{|r|}{$\underset{\text { ㄱ. }}{\text { ㄱ }}$} & \multicolumn{2}{|r|}{$\underset{\text { Na }}{\stackrel{N}{N}}$} & \multicolumn{2}{|r|}{$\stackrel{m}{\stackrel{n}{0}}$} & \multicolumn{2}{|r|}{ 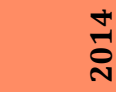 } \\
\hline & 这 & 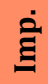 & 这 & ڤ̇ & 官 & 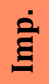 & 宅 & $\dot{\mathrm{g}}$ & 这 & 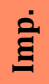 & 这 & $\dot{\mathrm{g}}$ \\
\hline Art Crafts & $\begin{array}{l}\text { Lூ } \\
\infty \\
\text { ஸे } \\
\text { ஸू }\end{array}$ & 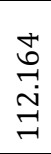 & 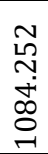 & $\begin{array}{l}\infty \\
\stackrel{+}{+} \\
\underset{-}{\sigma} \\
\stackrel{-}{\sigma}\end{array}$ & \begin{tabular}{l} 
L \\
\multirow{+}{+}{} \\
\multirow{+}{+}{} \\
\multirow{7}{*}{}
\end{tabular} & 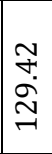 & $\begin{array}{l}0 \\
\text { } \\
\text { ñ } \\
\text { Ln } \\
\text { }\end{array}$ & 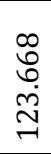 & 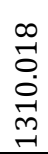 & 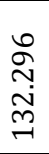 & 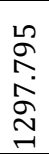 & 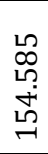 \\
\hline Audio visuals & 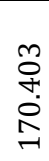 & \begin{tabular}{l}
$\stackrel{+}{N}$ \\
\multirow{J}{*}{}
\end{tabular} & $\begin{array}{l}0 \\
\stackrel{1}{\infty} \\
\infty \\
\infty \\
\infty\end{array}$ & 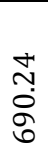 & $\begin{array}{l}\stackrel{\text { L }}{+} \\
m \\
m \\
\infty \\
\rightarrow\end{array}$ & $\begin{array}{l}\text { 오 } \\
\text { นூ } \\
\text { เึ่ } \\
\text { ஸூ }\end{array}$ & \begin{tabular}{l}
$\infty$ \\
10 \\
$\stackrel{+}{+}$ \\
\multirow{+}{*}{}
\end{tabular} & $\begin{array}{l}\underset{N}{N} \\
\underset{\sim}{\sim}\end{array}$ & $\begin{array}{l}\stackrel{+}{5} \\
\stackrel{5}{+} \\
\text { f }\end{array}$ & $\begin{array}{l}\text { N } \\
\text { O } \\
\stackrel{0}{0} \\
\stackrel{N}{\sim}\end{array}$ & $\begin{array}{l}0 \\
0 \\
0 \\
0 \\
+\end{array}$ & 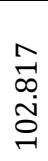 \\
\hline Design & $\begin{array}{l}\text { హे } \\
\text { ஸุ } \\
\text { مे } \\
\infty\end{array}$ & 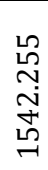 & $\begin{array}{l}\text { No } \\
\text { o. } \\
\text { N. } \\
\sigma\end{array}$ & 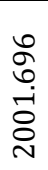 & 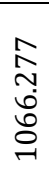 & 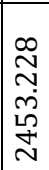 & 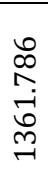 & 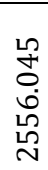 & 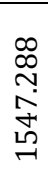 & $\begin{array}{l}\text { N } \\
\text { N̦} \\
\infty \\
\infty \\
\infty \\
\infty \\
\sim\end{array}$ & $\begin{array}{l}\text { 거 } \\
\infty \\
\infty \\
\infty \\
1+ \\
+\end{array}$ & $\begin{array}{l}\vec{\infty} \\
\stackrel{1}{1} \\
\underset{n}{N} \\
\stackrel{n}{n}\end{array}$ \\
\hline New media & $\begin{array}{l}\text { 이 } \\
\infty \\
\infty \\
\infty \\
\infty\end{array}$ & 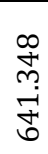 & 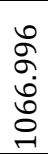 & 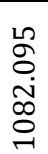 & 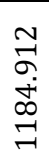 & $\begin{array}{l}\stackrel{N}{\hat{N}} \\
\stackrel{+}{+} \\
\stackrel{+}{+}\end{array}$ & 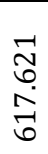 & $\begin{array}{l}\infty \\
\infty \\
1 \\
\text { ஸे } \\
\text { ஸै }\end{array}$ & $\begin{array}{l}\stackrel{m}{N} \\
\text { N} \\
\text { NV }\end{array}$ & $\begin{array}{l}\text { 여 } \\
\circ \\
\text { mூ } \\
\text { mb }\end{array}$ & $\begin{array}{l}\hat{m} \\
\hat{\sigma} \\
\text { م่ }\end{array}$ & 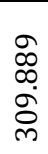 \\
\hline $\begin{array}{l}\text { Performing } \\
\text { arts }\end{array}$ & \begin{tabular}{l}
$\stackrel{\infty}{\Lambda}$ \\
$\stackrel{1}{+}$ \\
\multirow{+}{*}{}
\end{tabular} & $\begin{array}{l}\stackrel{\infty}{N} \\
\text { ஸ़ } \\
\infty \\
\infty\end{array}$ & 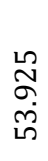 & $\begin{array}{l}\text { ळ } \\
\stackrel{+}{+} \\
\text { హ゙ }\end{array}$ & \begin{tabular}{l}
\multirow{Z}{*}{} \\
ti \\
Ln
\end{tabular} & $\begin{array}{l}0 \\
\sigma \\
\sigma \\
\\
\end{array}$ & $\begin{array}{l}\text { 음 } \\
\underset{7}{7}\end{array}$ & 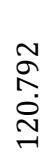 & 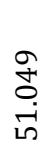 & 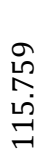 & 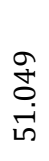 & 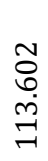 \\
\hline Publishing & 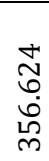 & $\begin{array}{l}\stackrel{1}{\circ} \\
\stackrel{-}{-} \\
\stackrel{\sim}{N} \\
\stackrel{\sim}{N}\end{array}$ & $\begin{array}{l}\stackrel{m}{+} \\
\stackrel{+}{+} \\
\stackrel{0}{n}\end{array}$ & 곤 & \begin{tabular}{l}
$m$ \\
$\stackrel{\infty}{+}$ \\
\multirow{+}{*}{}
\end{tabular} & 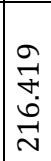 & \begin{tabular}{l} 
N \\
N \\
$\stackrel{0}{\sim}$ \\
\multirow{+}{*}{}
\end{tabular} & 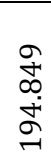 & 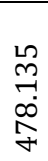 & $\begin{array}{l}\infty \\
\infty \\
m \\
\infty \\
\infty \\
\sim\end{array}$ & \begin{tabular}{c}
$\stackrel{\infty}{-}$ \\
$\stackrel{+}{+}$ \\
\multirow{2}{*}{}
\end{tabular} & $\begin{array}{l}0 \\
\text { ஸి } \\
\text { N } \\
\infty \\
-1\end{array}$ \\
\hline Visual arts & $\begin{array}{l}\text { N } \\
\text { กุ } \\
\text { N }\end{array}$ & 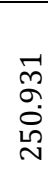 & 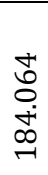 & $\begin{array}{l}\hat{ర} \\
\text { ᄂn } \\
\stackrel{\infty}{ } \\
\stackrel{N}{N}\end{array}$ & 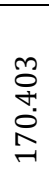 & 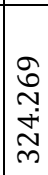 & $\begin{array}{l}\text { Vु } \\
\text { ָ} \\
\stackrel{+}{N}\end{array}$ & 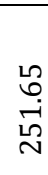 & 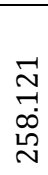 & $\begin{array}{l}\stackrel{+}{N} \\
\stackrel{\infty}{+} \\
\stackrel{+}{N}\end{array}$ & 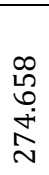 & 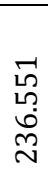 \\
\hline Total & 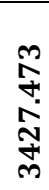 & $\begin{array}{l}10 \\
10 \\
10 \\
\text { లె } \\
\infty \\
\text { ले }\end{array}$ & 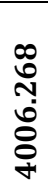 & 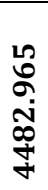 & $\begin{array}{l}0 \\
\stackrel{2}{N} \\
\infty \\
\infty \\
\infty \\
\stackrel{+}{+}\end{array}$ & $\begin{array}{l}\sigma \\
\hat{\gamma} \\
\infty \\
\infty \\
\sigma \\
\sigma \\
+\end{array}$ & 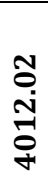 & 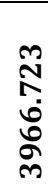 & 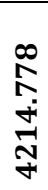 & 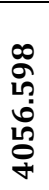 & $\begin{array}{l}\stackrel{+}{N} \\
\stackrel{n}{\sim} \\
\stackrel{7}{+}\end{array}$ & 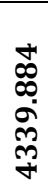 \\
\hline
\end{tabular}

Conversion from USD to Euros: 1 USD = 0.719 Euro (2009) constant prices.

Source: Own Elaboration with data from UNCTAD (2017).

Five of seven industries show a positive average annual growth in their exports, those are art crafts, 6.41\%; design, $13.03 \%$; performing arts, 3.53\%; publishing, $5.93 \%$, and visual arts, $2.30 \%$. The two industries that show a decrease were: audiovisuals, $-12.86 \%$, and new media, $-1.42 \%$. For the given period, the average annual growth of exports was 4.36\%. By 2014, the best-positioned activities were design, art crafts, and New Media. 
Regarding imports, three of the seven industries show a positive annual growth: art crafts, 6.78\%; design, 16.27\%; performing arts, 7.71\%. The other four show a negative growth: audiovisuals, $-21.71 \%$; new media, $-5.06 \%$; publishing, $-2.33 \%$ and visual arts, $0.22 \%$. The import's average annual growth for the period was 5.66\%. By 2014 the industry that imported more was design followed by new media and visual arts. In general, South Korea shows a negative trade balance, with a deficit of $-1.3 \%$.

Table 8. South Korea's Main Foreign Commercial Partners. Exports of Creative Goods from 2009 to 2014 (Millions of euros)

\begin{tabular}{|c|l|r|r|r|r|r|r|}
\hline Rank & \multicolumn{1}{|c|}{ Partner } & $\mathbf{2 0 0 9}$ & $\mathbf{2 0 1 0}$ & $\mathbf{2 0 1 1}$ & $\mathbf{2 0 1 2}$ & $\mathbf{2 0 1 3}$ & \multicolumn{1}{|c|}{$\mathbf{2 0 1 4}$} \\
\hline $\mathbf{1}$ & $\begin{array}{l}\text { People's Republic } \\
\text { of China }\end{array}$ & 346.558 & 500.424 & 606.836 & 527.027 & 555.787 & 575.2 \\
\hline $\mathbf{2}$ & $\begin{array}{l}\text { United States of } \\
\text { America }\end{array}$ & 425.648 & 458.003 & 457.284 & 494.672 & 517.68 & 568.01 \\
\hline $\mathbf{3}$ & Vietnam & 198.444 & 242.303 & 312.046 & 358.062 & 448.656 & 508.333 \\
\hline $\mathbf{4}$ & Hong Kong SAR & 480.292 & 424.21 & 555.787 & 379.632 & 331.459 & 371.723 \\
\hline $\mathbf{5}$ & Japan & 373.88 & 399.764 & 374.599 & 435.714 & 331.459 & 335.773 \\
\hline $\mathbf{6}$ & Indonesia & 140.924 & 175.436 & 217.138 & 239.427 & 240.146 & 244.46 \\
\hline $\mathbf{7}$ & India & 115.759 & 132.296 & 143.081 & 110.726 & 143.8 & 145.957 \\
\hline $\mathbf{8}$ & United Arab & 107.131 & 124.387 & 125.106 & 129.42 & 135.172 & 129.42 \\
\hline $\mathbf{9}$ & $\begin{array}{l}\text { China, Taiwan } \\
\text { Province of }\end{array}$ & 227.204 & 337.211 & 355.905 & 166.808 & 102.098 & 99.941 \\
\hline $\mathbf{1 0}$ & Philippines & 43.859 & 53.206 & 69.743 & 81.247 & 92.032 & 90.594 \\
\hline
\end{tabular}

Conversion from USD to Euros: 1 USD $=0.719$ Euro (2009) constant prices.

Source: Own elaboration with information from UNCTAD (2017)

Creative industries in South Korea have dynamic, international commerce. In 2009, Hong Kong was its main business partner, followed by the United States of America. But, in 2014 China was positioned as their main foreign business partner, while the USA remained in second place.

The information above reflects the importance of international trade for the development of the creative economy in South Korea. In this regard, by 2014 the most dynamic industries were designed, making 35\% of the total exports and representing $74 \%$ of the total creative industries, and art crafts made $31 \%$ of the total exports and only $3.5 \%$ of the total imports. Moreover, this country has an important network of institutions that foster the development of cultural and creative industries.

\section{Mexico's creative economy and its impact on the development}

With information and data from Valdivia et al. (2020), we know that approximately $10 \%$ of the workforce in Mexico is involved in creative occupations. By 2019, there were about 100 thousand productive units related to creative activities, which were mainly located in the Metropolitan Zones of Valle de Mexico, Queretaro, Merida, Tijuana, Guadalajara, Cancun, Pachuca, and Leon.

In 2015 , the country exported about six thousand million dollars of creative goods. On the other hand, creative services represent $33 \%$ of the aggregate value of the industry, while arts, R\&D, entertainment, and software represent $17 \%$ each. This last one is the most dynamic of all.

According to the same authors (Valdivia et al., 2020), there are not enough research works with complete analysis about the impact of creative economies in the development of Mexico. They also mentioned the necessity of a more accurate 
classification for the cultural and creative industries (CCI) to understand their advantages. The current classification uses the terminology and codes of the Industrial Classification System for North America (SCIAN) since they are also used in the Mexican statistics regarding its economic sectors. This system classifies the cultural and creative industries into twelve generic groups, which is helpful to make comparative analyses against other regions. However, these authors propose to reclassify these activities into five groups: arts, creative services, software, $R \& D$, and entertainment. This proposal is appropriate since these five sectors concentrate more than $90 \%$ of the creative industries in the country.

Valdivia et al. (2020) used information from two important databases generated by the National Institute of Statistics and Geography, INEGI in Mexico. The first source is the Economic Censuses which offer a lot of valuable information disaggregated by regions and sectors, but it's limited in terms of occupations and employment. The second source is the National Surveys of Occupation and Employment (ENOE, by its initials in Spanish), which provide good information to create indicators about creative jobs, but they are not specific about the sector they belong to.

Table 9. Creative Jobs in Mexico, 2005 and 2018.

\begin{tabular}{|l|c|c|c|c|c|}
\hline & $\mathbf{2 0 0 5}$ & $\mathbf{2 0 1 8}$ & \multicolumn{2}{c|}{$\begin{array}{c}\text { Participation } \\
\text { from total (\%) }\end{array}$} & $\begin{array}{c}\text { Annual } \\
\text { average } \\
\text { growth rate } \\
\text { 2005-2018 }\end{array}$ \\
\cline { 4 - 6 } & & & $\mathbf{2 0 0 5}$ & $\mathbf{2 0 1 8}$ & 1.9 \\
\hline Total employed population & $40,321,130$ & $51,473,960$ & 100.0 & 100.0 & 2.4 \\
\hline Jobs in creative industries & $2,870,550$ & $3,889,350$ & 7.1 & 7.6 & 3.0 \\
\hline Creative trident & $1,366,628$ & $2,018,586$ & 3.4 & 3.9 & 2.5 \\
\hline Creative specialists & $3,771,544$ & $5,184,459$ & 9.4 & 10.1 & 3.4 \\
\hline $\begin{array}{l}\text { Non-creative workers in } \\
\text { creative industries }\end{array}$ & 465,634 & 723,477 & 1.2 & 1.4 & \\
\hline $\begin{array}{l}\text { Creative workers in non- } \\
\text { creative industries }\end{array}$ & 900,994 & $1,295,109$ & 2.2 & 2.5 & 2.8 \\
\hline
\end{tabular}

Notes: If the number of jobs is bigger than the number of workers in creative industries, it may mean that there are employees who participate in more than one creative activity. This may mean that there is a deficit of creative individuals in the country.

Creative Trident $=$ Creative specialists + Non-creative in Creative Industries + Creative in noncreative sectors.

Source: Data from the second trimester of ENOE, 2005 and 2017; Valdivia et al. (2020)

In 2005 there were 2,870,550 people employed in creative industries, which represented $7.1 \%$ of the total employment in Mexico. From the total employed population, $1.2 \%$ were creative specialists and $2.2 \%$ were non-creative workers working in a creative sector.

From table 9, all the employment indicators showed an increment from 2005 to 2018. Creative jobs increased $0.5 \%$ from the total participation. The number of creative specialists increased by $0.2 \%$, the same as the number of creative workers in noncreative industries. The non-creative workers working in creative industries increased their participation by $0.3 \%$.

Table 10. Comparative Analysis of the economic units (firms) in the Cultural and Creative Industries. 2014, 2015, and 2019

\begin{tabular}{|l|c|c|c|c|c|c|}
\hline \multirow{2}{*}{ Creative Sectors } & \multicolumn{3}{|c|}{ Economic Units } & \multicolumn{3}{c|}{ \% in creative industries } \\
\cline { 2 - 7 } & $\mathbf{2 0 1 4}$ & $\mathbf{2 0 1 5}$ & $\mathbf{2 0 1 9}$ & $\mathbf{2 0 1 4}$ & $\mathbf{2 0 1 5}$ & $\mathbf{2 0 1 9}$ \\
\hline Publishing Activities & 1,201 & 1,569 & 1,678 & 1.8 & 1.5 & 1.5 \\
\hline Film, Video and Sound Industry & 1,027 & 1,227 & 1,635 & 1.5 & 1.2 & 1.5 \\
\hline $\begin{array}{l}\text { TV programming and } \\
\text { broadcasting activities }\end{array}$ & 890 & 1,852 & 1,996 & 1.3 & 1.8 & 1.8 \\
\hline $\begin{array}{l}\text { Computer programming, } \\
\text { Consultancy and others }\end{array}$ & 2,661 & 3,317 & 4,203 & 4.0 & 3.1 & 3.8 \\
\hline
\end{tabular}


52 | Santos LOPEZ-LEYVA, Gilberto GUZMÁN-SOLANO

The Creative Economy as a Factor of Economic Development: Three Different Cases, One Common Objective

\begin{tabular}{|l|c|c|c|c|c|c|} 
Architecture & 5,487 & 6,326 & 6,983 & 8.2 & 6.0 & 6.3 \\
\hline R \& D & 1,177 & 2,133 & 2,455 & 1.8 & 2.0 & 2.2 \\
\hline $\begin{array}{l}\text { Advertising and Marketing } \\
\text { Research }\end{array}$ & 6,821 & 8,332 & 8,854 & 10.1 & 7.9 & 7.9 \\
\hline Design and photography & 9,532 & 14,511 & 14,188 & 14.2 & 13.7 & 12.7 \\
\hline $\begin{array}{l}\text { Artistic Creation and } \\
\text { Entertainment }\end{array}$ & 1,777 & 4,158 & 4,165 & 2.6 & 3.9 & 3.7 \\
\hline Libraries and Museums & 241 & 5,997 & 6,085 & 0.4 & 5.7 & 5.5 \\
\hline Gaming and Gambling & 4,659 & 5,385 & 5,469 & 6.9 & 5.1 & 4.9 \\
\hline Sports and Entertainment & 31,698 & 50,997 & 53,837 & 47.2 & 48.2 & 48.3 \\
\hline Total CCI & 67,171 & 105,804 & 111,548 & 100.0 & 100.0 & 100.0 \\
\hline
\end{tabular}

Source: INEGI (2014); Economic Census, 2014; ENOE, 2014 and 2019; Valdivia et al. (2020)

In 2019, Mexico had a total of 111,548 enterprises within the cultural and creative industries. The majority of the companies belonged to the sport and entertainment sector, representing $48.3 \%$ of the total industries. Considering the number of enterprises, the rest of the industry is ranked as follows: design and photography, advertising and marketing research, architecture, libraries and museums, gaming and gambling, computer programming consultancy and others, artistic creation and entertainment, R\&D, TV programming and broadcasting activities, publishing and at last the film, video and sound industry.

From 2014 to 2019, the sectors that registered higher growth in the number of economic units were: in the first place, sports and entertainment with 22,139 more enterprises, surpassing 3.78 times the second place, libraries, and museums; in third place was the creative sector of design and photography with an increment of 4,656 economic units. The less dynamic sectors that showed the smallest growth were gaming and gambling, film, Video and Sound, and Publishing.

Table 11. Structure and Growth Rate of the Creative Jobs in Mexico, 2005-2018

\begin{tabular}{|l|c|c|c|c|c|}
\hline & $\mathbf{2 0 0 5}$ & $\mathbf{2 0 1 8}$ & $\mathbf{2 0 0 5}$ & $\mathbf{2 0 1 8}$ & $\begin{array}{c}\text { Growth rate } \\
\mathbf{2 0 0 5}-\mathbf{2 0 1 8}\end{array}$ \\
\hline Creative jobs & $2,870,550$ & $3,889,350$ & 100.0 & 100.0 & 2.4 \\
\hline Advertising and Marketing & 395,603 & 446,529 & 13.8 & 11.5 & 0.9 \\
\hline Architecture & 130,259 & 175,794 & 4.5 & 4.5 & 2.3 \\
\hline Design and Visual Arts & 131,384 & 212,952 & 4.6 & 5.5 & 3.8 \\
\hline Artisans & $1,066,999$ & $1,234,326$ & 37.2 & 31.7 & 1.1 \\
\hline Executive Artisans & & 27,498 & 0.0 & 0.7 & \\
\hline Film, Video and Photography & 104,682 & 150,666 & 3.6 & 3.9 & 2.8 \\
\hline Radio and Television & 8,736 & 5,201 & 0.3 & 0.1 & -3.9 \\
\hline TV and Radio Executives & & 7,456 & 0.0 & 0.2 & \\
\hline Fashion and Performing Arts & 144,429 & 149,067 & 5.0 & 3.8 & 0.2 \\
\hline $\begin{array}{l}\text { Executives of Artistic } \\
\text { Activities }\end{array}$ & 23,121 & 26,506 & 0.8 & 0.7 & 1.1 \\
\hline Publishing & 36,306 & 35,751 & 1.3 & 0.9 & -0.1 \\
\hline $\begin{array}{l}\text { Software, Information } \\
\text { Technology and Consultancy }\end{array}$ & 332,802 & 563,516 & 11.6 & 14.5 & 4.1 \\
\hline Software Executives & 43,866 & 32,840 & 1.5 & 0.8 & -2.2 \\
\hline R \& D & 320,613 & 721,694 & 11.2 & 18.6 & 6.4 \\
\hline R \& D Executives & 131,750 & 99,554 & 4.6 & 2.6 & -2.1 \\
\hline
\end{tabular}

Source: Data from ENOE (Second trimester of 2005 and 2018); Valdivia et al. (2020)

According to the information given in table 11, from 2005 to 2018, there were 1,018,800 new jobs in the creative industries, which represented an annual growth rate of $2.4 \%$. The sectors that created more jobs during the period were: R\&D (401,081 new jobs, $6.4 \%$ growth rate); software, information technology, and consultancy $(230,714$ new jobs, $4.1 \%$ growth rate); and Artisans (167,327 new jobs, 1.1\% growth rate). On the other hand, the creative sectors that lost jobs during the period were: radio and television $(-3,535$ jobs), software executives $(-11,026$ jobs $)$, and R\&D Executives (32,196 jobs). 
Regarding the number of creative jobs in Mexico, by 2018, the sectors with the highest percentage of creative workers were: 1) artisans representing $31.7 \%$ of the total, 2) the R\&D sector representing $18.6 \%$ from the total and, 3) software, information technology and consultancy with $14.5 \%$. These numbers are the result of the actions taken by the country, such as giving financial support to the R\&D sector through scholarships. Mexico is immersed in the digital economy; this has become essential for the socio-political system, the productive sectors, and academic life, which explains the creation of more jobs in sectors such as Software, Information Technology, and Consultancy. Although, it is also known that the greater part of the population is still working with rudimentary processes and many have poor education, which explains the fact that most of the creative jobs are in the sector of artisans, doing tasks that do not require high knowledge or technology.

The four sectors with the lowest percentage of creative jobs are executive artisans and executives of artistic activities, both with $0.7 \%$, followed by executives of radio and TV with $0.2 \%$ and Radio and TV with $0.1 \%$.

Table 12. Creative jobs and Types of Remuneration, 2005 and 2018.

\begin{tabular}{|l|c|c|c|c|}
\hline \multirow{2}{*}{\multicolumn{1}{c}{ Type of creative jobs }} & \multicolumn{2}{c|}{ Total Economy } & \multicolumn{2}{c|}{ Creative jobs } \\
\cline { 2 - 5 } & $\mathbf{2 0 0 5}$ & $\mathbf{2 0 1 8}$ & $\mathbf{2 0 0 5}$ & $\mathbf{2 0 1 8}$ \\
\hline Paid workers & 65.8 & 70.3 & 64.1 & 65.7 \\
\hline Employers & 4.6 & 4.6 & 7.4 & 7.5 \\
\hline Self employed & 22.0 & 20.5 & 26.1 & 24.7 \\
\hline Unpaid workers & 7.5 & 4.6 & 2.4 & 2.0 \\
\hline Total & 100.0 & 100.0 & 100.0 & 100.0 \\
\hline
\end{tabular}

Source: Data from ENOE, Second trimester, 2005 and 2018; Valdivia et al. (2020)

Table 12 shows the type of jobs and remuneration obtained by workers in the creative industries in Mexico. From the analysis, the following is observed:

- In both years, the percentage of employers in the creative sectors was higher than the employers in the total economy. Also, the percentage of self-employed in the creative sectors is higher than in the total economy.

- Most of the labor force in the creative sectors is paid workers, although compared to the total economy; the percentage of paid workers in creative sectors is slightly smaller than the total economy.

- The percentage of unpaid workers in the creative sectors is smaller than in the total economy, but this is still a problem because most of these workers do not have the benefits that the law offered to workers with formal paid jobs.

- The percentage of unpaid and self-employed workers decreased from 2005 to 2018 , which can be considered as positive if the workers are now participating in formal jobs.

- The percentage of self-employed workers within the creative sectors $(24.7 \%$ in 2018) can be explained by the fact that many artists and people dedicated to creative activities work isolated or independently. 
Table 13. Aggregate value, Employment and International Commerce of the Creative Economic Sectors in Mexico. Information obtained from the Culture Satellite Account presented by INEGI (2008 and 2018)

\begin{tabular}{|c|c|c|c|c|c|c|c|c|}
\hline \multirow[t]{2}{*}{ General areas } & \multicolumn{2}{|c|}{$\begin{array}{l}\text { Aggregate value (Constant } \\
\text { Million of Euros) }\end{array}$} & \multicolumn{2}{|c|}{ Number of jobs } & \multicolumn{2}{|c|}{$\begin{array}{c}\text { Exports } \\
\text { (Constant millions of } \\
\text { Euros) }\end{array}$} & \multicolumn{2}{|c|}{$\begin{array}{c}\text { Imports } \\
\text { (Constant millions of } \\
\text { Euros) }\end{array}$} \\
\hline & 2008 & $2018(p)$ & 2008 & $2018(p)$ & 2008 & $2018(p)$ & 2008 & $2018(p)$ \\
\hline Culture (Total) & 29860.55 & 45201.45 & $1,277,482$ & $1,395,669$ & 754.66 & 819.92 & 3758.85 & 2715.79 \\
\hline General and specific areas (Sub-total) & 24663.44 & 38919.75 & $1,051,671$ & $1,139,367$ & 754.66 & 819.92 & 3758.85 & 2715.79 \\
\hline Visual and Plastic Arts & 511.73 & 458.24 & 21,966 & 23,049 & 249.19 & 44.11 & 583.90 & 473.92 \\
\hline Performing Arts and Shows & 1547.62 & 1967.13 & 22,633 & 22,353 & 0.31 & 0.12 & 0.55 & 0.74 \\
\hline Music and Concerts & 486.73 & 382.81 & 44,892 & 48,442 & 121.38 & 21.02 & 488.87 & 165.80 \\
\hline Books, Printings and Press & 1579.91 & 1229.57 & 87,027 & 74,573 & 111.02 & 106.79 & 618.83 & 484.40 \\
\hline Audiovisual Media & 10763.24 & 23490.24 & 184,573 & 194,939 & 271.92 & 647.44 & 2061.61 & 1582.91 \\
\hline Handicrafts & 5268.24 & 6278.09 & 434,563 & 498,151 & & & & \\
\hline Design and Creative Services & 2475.55 & 2961.24 & 142,724 & 154,836 & 0.55 & 0.31 & 2.94 & 5.45 \\
\hline Natural and Material Heritage & 564.79 & 551.43 & 32,201 & 35,368 & 0.31 & 0.06 & 2.14 & 2.51 \\
\hline $\begin{array}{l}\text { Formation and Promotion of Culture in } \\
\text { Educational Institutions }\end{array}$ & 1465.58 & 1601.05 & 81,092 & 87,656 & $\mathrm{~N} / \mathrm{A}$ & $\mathrm{N} / \mathrm{A}$ & $\mathrm{N} / \mathrm{A}$ & $\mathrm{N} / \mathrm{A}$ \\
\hline Household Production of Cultural goods & 5197.04 & 6281.71 & 225,811 & 256,302 & $\mathrm{~N} / \mathrm{A}$ & $\mathrm{N} / \mathrm{A}$ & $\mathrm{N} / \mathrm{A}$ & $\mathrm{N} / \mathrm{A}$ \\
\hline
\end{tabular}

Conversion from Mexican Peso (MXN) to Euros: 1 MXNPeso $=0.06127$ Euro (2008) constant prices.

(p): Preliminary numbers; N/A: It does not apply.

Source: Data from the Satellite Account about Culture in Mexico; INEGI; Valdivia et al. (2020) 
By comparing the data from 2008 and 2018, we observed the following:

1) The cultural sector increased its aggregate value by $51.37 \%$.

2) Audiovisual media had the best economic performance; its added value increased by 12,727 million Euros. In second and third places were the sectors of household production of cultural goods and handicraft with an increment of 1,084.67 million Euros and 1,009.85 million Euros, respectively. The three areas with the worst performance, showing a decreasing indicator were: visual and plastic arts (-53.49 million Euros), music and concerts (-103.92 million Euros), and books, printings, and press (-350.34 million of Euros).

3) The number of jobs within all the cultural activities increased by 118,187 . The areas that showed a higher increment were: handicrafts, 63,588 new jobs; household production of cultural goods, 30,491; design and creative services, 12,112; the area with the smallest growth was visual and plastic arts, with only 1,083 new jobs in 10 years. On the other hand, the areas with negative numbers were performing arts and shows, -280 jobs, and books, printings, and press, $-12,454$ jobs.

4) The trade balance of cultural activities showed a deficit for both years, $-3,004.19$ million euros in 2008 and -1.8095 .87 million euros in 2018. All sectors had higher imports than exports, but the three areas that in 2008 had the greatest deficits were: audiovisual media $(-1,789.69$ million euros), books, printing, and press (507.81 million of euros), and music and concerts ( -367.49 million of euros). In 2018, the dynamic was slightly different, since the sector of audiovisual media

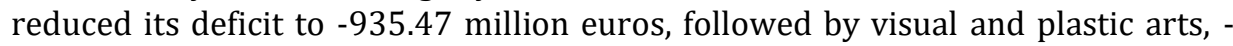
429.81 million euros, and books, printings, and press, -377.61 million of euros. The big deficit in the international trade of the audiovisual media sector could be explained by the influence of the US film industry in Mexico, which is found among the ten countries that create the highest demand for US movies.

For Mexico, it is possible to apply what Veselá \& Klimová (2014) propose for the case of Slovakia, that one way to reduce the economic and financial crisis is to stimulate the growth of the economy by promoting the creative economy, which can occur in all areas of human activity.

\section{Conclusions}

Each nation acknowledges the concept of "creative economy" differently; even among the scholars, there is not a conclusive agreement about the activities that must be considered as part of this type of economy, which makes it more difficult to have homogeneous statistics to make comparison analysis among the nations. Therefore, it is necessary to create a more homogenized system of indicators to make regional comparisons.

Governments, the private sector, and workers from developed countries have been paying more attention to creative industries. Part of the population that is not involved in standardized production processes has been displaced, even being highly skilled. The increase of automated and standardized processes within the economy has had an impact on the workforce. A large quantity of workers has been laid off, even when they have the knowledge and the training. However, the great majority of countries, including Mexico, lack public policies, plans, and specific strategies to strengthen their creative sectors, even though it is known that they are important and add value to the economy.

In 2013, the government of the Republic of South Korea included in their national agenda the importance of "creative economies" by implementing a strategic plan toward 
strengthening all creative activities. This plan was led by the Ministry of Science, ICT and Future Planning (MSIP) and it included the creation of start-ups, enterprising, creation of jobs, financial support to researchers, "angel" investments, creation of crowdfunding, supporting small and medium businesses, the incorporation of creative companies to the Stock Exchange Market, fostering the exportation of creative products and services, intellectual property rights, among other actions (MSIP, 2013).

In the United Kingdom, the creative industries have great importance. They hold more than 2 million jobs and the employment rate has grown $30.6 \%$ since 2011, and $87 \%$ of the jobs in this sector have a low risk of automation. There are more than 289,000 creative enterprises, representing $11.9 \%$ of all the companies in the UK. It is noteworthy that $94.8 \%$ of the enterprises are micro-enterprises (with less than 10 employees). The sector generates $5.5 \%$ of the total economy (CIF, 2019).

Mexico has had important achievements in some creative activities, such as the film industry, which have demonstrated having a great potential for the economic development of the regions where the films have taken place. Mexico is also recognized for its cultural diversity, archeological sites, and internationally recognized musical identity. The country has important television companies and a bigger number of AM and FM radio stations.

These are just some of Mexico's strengths, even though these activities can be considered as cultural rather than creative if their potential could be used and the country implements strategic plans to encourage creative activities and strengthen property rights, they could create a positive impact on economic growth.

The main problem is not having an integrated national public policy that combines the potentialities of cultural and creative activities. They just have been developed independently, without an incentive or linkages.

Some important facts regarding the creative industry in the three economies are:

1. $10 \%$ of the United Kingdom's total employment belongs to this sector, in South Korea around 4\% (Deloitte, 2021) and Mexico 3.4\% (Valdivia et al. 2020).

2. Comparing data regarding the number of companies in the advertising sector of the United Kingdom and Mexico, we found that for the 2011-2014 period, the UK had 22,195 companies (data from table 2), while in 2014 Mexico only had 6,821 companies (data from table 10), that is one-third of the companies in the United Kingdom. It should be noted that the number for Mexico, also includes companies within the marketing research sector.

3. Regarding the homogenization of data and their use to do comparative analysis among the countries, we have the following observations: While in the UK, Film, Radio, and TV are part of the same industry, in Mexico, this sector is disaggregated in two: the Film, Video and Sound Industry and TV programming and broadcasting activities. Another sector with a similar difficulty is Music and Performing Arts in the UK that should be comparable to the sectors of Music, Film and Video, and Artistic Creation and Entertainment sectors in Mexico.

4. Other sectors that have homogeneity are architecture and publishing, but it is necessary to understand in the same way these activities to these two economies. According to data architecture had 13,765 economic units in the UK (2011-2014) and Mexico (just in 2014) 5,487, on the other hand, Publishing in the UK (2011-2014 period) had 10,003 and México (2014) 1,201.

5. To facilitate the performance of comparative analysis by countries, it is necessary to take actions to homogenize data among the countries, which will also contribute to obtaining better research works. 


\section{References}

Bilan, Y., Vasilyeva, T., Kryklii, O. \& Shilimbetova, G. (2019). The creative industry as a factor in the development of the economy: dissemination of European experience in the countries with economies in transition. Creativity Studies, 12 (1), 75-101. https://doi.org/10.3846/cs.2019.7453

Buitrago, F., \& Duque, I. (2013). Economía Naranja. Una oportunidad infinita [The Orange Economy. An infinite opportunity]. Interamerican Development Bank.

CIF (Creative Industries Federation). (2019). The UK's creative industries. What are the creative industries?. https://www.creativeindustriesfederation.com/statistics

Cornell, S. (2014). Building a creative economy in South Korea. Analyzing the plans and possibilities for the new economic growth. Korea's Domestic Economy. On Korea 2014: Academic Paper Series (vol. 7, pp. 3-21), KEI.

CSCM. (2019). Cuenta Satélite de la Cultura de México [Satellite Account of the Culture of Mexico]. INEGI.

Daubaraité, U.. \& Startiené, G. (2015). Creative industries impact on national economy in regard to sub-sectors. Procedia-Social and Behavioral Sciences, 213(2015), 129134. https://doi.org/10.1016/j.sbspro.2015.11.415

Deloitte. (2021). The future of the Creative Economy. A report by Deloitte. https://www2.deloitte.com/uk/en/pages/technology-media-andtelecommunications/articles/the-future-of-the-creative-economy.html

DENUE. (2015). Directorio Estadístico Nacional de Unidades Económicas de México [National Statistical Directory of Economic Units of Mexico]. INEGI.

DENUE. (2019). Directorio Estadístico Nacional de Unidades Económicas de México [National Statistical Directory of Economic Units of Mexico]. INEGI.

Daubaraité, U. (2018). Creative industries' impact on national economy. Summary of Doctoral Dissertation. Kaunas University of Technology. https://epubl.ktu.edu/object/elaba:27362998

INEGI. (2014). Economic Census 2014 of México. INEGI

ENOE. (2005). Encuesta Nacional de Ocupación y Empleo de México. INEGI

ENOE. (2018). Encuesta Nacional de Ocupación y Empleo de México. INEGI

Florida, R. (2013, January 30). More Losers than Winners in America's New Economy Geography. Bloomberg. https://www.bloomberg.com/news/articles/2013-0130/more-losers-than-winners-in-america-s-new-economic-geography

Frey, C. B., \& Osborne, M. A. (2017). The Future of Employment: How Susceptible Are Jobs to Computerization?. Technological Forecasting and Social Change 114, 254280. https://doi.org/10.1016/i.techfore.2016.08.019

Frey, C. B. (2019). The Technology Trap. Capital, Labor and Power in the Age of Automation. Princeton University Press.

Gregory, P. R., \& Stuart, R. C. (2014). The global economy and its economic systems. South Western, Cengage Learning.

Guilera, L. (2020). Anatomía de la Creatividad [The Anatomy of Creativity]. Merge Books.

Hartley, J., \& Potts, J. (2014). Cultural Science: A Natural History of Stories, Demes, Knowledge and Innovation. Bloomsbury Academic.

Hartley, J., Wen, W., \& Siling Li, H. (2015). Creative Economy and Culture. Challenges, Changes and Futures for The Creative Industries. SAGE

Howkins J. (2013). The Creative Economy. How people make Money from ideas. Penguin Global.

Inter American Development Bank (IDB) (2017). Economía Naranja. Innovaciones que no sabías que eran de América Latina y el Caribe. IBD.

Landry, C. (2001). The Creative City. Earthscan-Comedia.

Luzardo, A., De Jesús, D., \& López, M. (2017). Economía Naranja. Innovaciones que no sabías que eran de América Latina y el Caribe [Orange Economy. Innovations you didn't know were from Latin America and the Caribbean]. Interamerican Development Bank

MSIP. (2013). Ministry of Science, ICT and Future Planning Overview. https://pitchbook.com/profiles/limited-partner/179186-59\#overview

NESTA. (2014). National Endowment for Science Technology and Arts. Interactive map. 
58 | Santos LOPEZ-LEYVA, Gilberto GUZMÁN-SOLANO

The Creative Economy as a Factor of Economic Development: Three Different Cases, One Common Objective

https://www.nesta.org.uk/data-visualisation-and-interactive/interactive-mapgeography-creativity-uk/

OIT. (2004). Programa global: Invirtiendo en empleo para la reducción de la pobreza y el crecimiento económico local. Documento de Programa del Servicio de Inversiones con Alto Coeficiente de Empleo - EMP/INVEST [Global Program: Investing in Employment for Poverty Reduction and Local Economic Growth. Programme Document of the Investment Service with High Employment Coefficient - EMP/INVEST]. Organización Internacional del Trabajo/ International Labor Organization.

UNCTAD. (2017). Strengthening the creative industries for development in the Republic of Korea. United Nations.

UNDP, \& UNESCO (2013). Creative Economy Report 2013. Special Edition. Widening Local Development Pathways. United Nations.

Valdivia, M., Quintana, L., Mendoza M. \& Rodríguez I. (2020). Economía Creativa en las Ciudades de México. Un estudio sobre la presencia y vinculaciones de las Industrias-Ocupaciones Creativas y Culturales en el sistema urbano de México [Creative Economy in Mexico City. A study on the presence and linkages of Industries-Creative and Cultural Occupations in the urban system of Mexico]. Universidad Nacional Autónoma de México.

Veselá, D., \& Klimová, K (2014). Knowledge-based economy vs. creative economy. Procedia-Social and Behavioral Sciences, 141(2014), 413-417. https://doi.org/10.1016/j.sbspro.2014.05.072

Received: August 17, 2021

Accepted: November 28, 2021

\section{Author biographies}

Santos Lopez-Leyva holds a Ph.D. in Economics: Economics of Science and Technology from the National Autonomous University of Mexico. He is a Professor of economic development, the economics of education, and research methodology at the Autonomous University of Baja California campus Tijuana, México. Since 1998 he is a member of the National System of Researchers and the Mexican Academy of Sciences.

Gilberto Guzmán-Solano has a Master's degree and a Ph.D. in Global Development Studies by the Autonomous University of Baja California, campus Tijuana, México. He is a member of the Mexican Association of International Studies (AMEI, A.C.). 